\title{
PANDEMIA DE COVID-19 NO BRASIL: PRIMEIROS IMPACTOS SOBRE AGREGADOS MACROECONÔMICOS E COMÉRCIO EXTERIOR'
}

\author{
Juliana Carvalho da Cunha Trece
}

\begin{abstract}
SINOPSE
A pandemia de Covid-19, iniciada na China no final de 2019, abalou a economia global, levando o mundo a entrar em recessão em 2020. A economia brasileira, que já enfrentava desafios antes da pandemia, alcançou recordes negativos de variação em diversos agregados macroeconômicos a partir da necessidade de adoção de medidas de distanciamento social com o objetivo de reduzir o ritmo de contágio do vírus, o que deixou a situação brasileira ainda mais desafiadora em termos macroeconômicos. Neste texto, busca-se mensurar os primeiros impactos da pandemia na economia brasileira com base na análise dos fluxos macroeconômicos de oferta e demanda agregada de produtos. Além disso, analisa-se 0 comportamento dos coeficientes de exportações e de penetração das importações a partir da chegada da pandemia ao país.
\end{abstract}

Palavras-chave: pandemia de Covid-19; economia brasileira; coeficiente de exportação; coeficiente de penetração das importações.

\begin{abstract}
The Covid-19 pandemic, which began in China by the end of 2019, has shaken the global economy, driving the world into recession in 2020. The Brazilian economy, which already faced challenges before the pandemic, reached negative records of variations in several macroeconomic aggregates due to the need to adopt measures of social distancing to reduce the rate of contagion of the virus. This article seeks to measure the first impacts of the Covid-19 pandemic on the Brazilian economy looking into the macroeconomic flows of aggregate supply and demand for products. In addition, an analysis of the behavior of export and import coefficients, after the arrival of the pandemic in the country, is carried out.
\end{abstract}

Keywords: Covid-19 pandemic; Brazilian economy; export coefficient; import penetration coefficient.

JEL: A10; E00; E01; E66; F00; F62.

Artigo recebido em 31/7/2020 e aprovado em 8/8/2020.

DOI: http://dx.doi.org/10.38116/bepi27art2

\section{INTRODUÇÃO}

A pandemia de Covid-19 iniciou-se na China ao final de 2019 e, a partir de 2020, transformou as relaçôes sociais e econômicas ao redor do mundo, conforme o vírus foi se disseminando pelos países. A implementação de medidas de isolamento social, como a suspensão de aulas presenciais, eventos esportivos e religiosos, além do fechamento de cinemas, teatros, restaurantes e bares, a fim de evitar aglomeraçôes e, com isso, a diminuição do ritmo de contágio do vírus, tem sido extremamente importante para a preservação de vidas mediante a redução do pico de incidência da doença. Tais medidas foram

\footnotetext{
1. A autora agradece a Claudio Considera e a Marcel Balassiano pelos comentários e pelas sugestões e a André Luiz de Souza pela extração e pelo tratamento da base de dados da Secretaria de Comércio Exterior (SECEX).

2. Economista do Núcleo de Contas Nacionais do Instituto Brasileiro de Economia da Fundação Getulio Vargas (IBRE/FGV); e doutoranda em população, território e estatísticas públicas na Escola Nacional de Ciências Estatísticas do Instituto Brasileiro de Geografia e Estatística (ENCE/IBGE).
} 
adotadas para que os sistemas de saúde dos países não colapsassem e, assim, milhares de vidas pudessem ser salvas por meio de tratamento médico adequado (Sen-Crowe, Mckenney e Elkbuli, 2020).

A adoção das medidas trouxe, no entanto, enormes desafios em termos econômicos, com as expectativas de crescimento das economias sendo bruscamente reduzidas para 2020 em todo o mundo, de tal forma que se iniciou um debate sobre se a causa da forte recessão era a pandemia em si ou as medidas de isolamento adotadas para controlar o vírus. ${ }^{3}$

A crise global de saúde gerou uma grave recessão econômica mundial de caráter inédito, com expectativa de contração econômica mais intensa que a observada na crise financeira de 2008-2009 (IMF, 2020). ${ }^{4}$ Esta é a décima quarta recessão mundial dos últimos 150 anos, e a quarta mais forte deste período, ficando atrás apenas das recessôes das duas guerras mundiais e da crise da Grande Depressão em 1929 (World Bank, 2020). ${ }^{5}$ Esse cenário se configura a partir não somente da disseminação da pandemia pelo mundo, mas também das incertezas com relação à sua duração, tendo em vista que, até o momento, não há vacina ou remédio que combata o vírus. Mesmo que em diversos países o isolamento social já tenha sido reduzido, o vírus ainda não está controlado e, portanto, novas ondas de contágio não são descartadas.

O Brasil, que é um dos países com maiores números de casos e de mortes pelo vírus, segundo os dados da Organização Mundial da Saúde (OMS) divulgados em 29 de julho deste ano, tem enfrentado desafios a fim de superar a crise atual que se iniciou no primeiro trimestre de 2020 (FGV e IBRE, 2020). O país já enfrentava dificuldades para ter crescimento mais robusto no último período expansivo da economia brasileira, que durou de 2017 a 2019, em uma recuperação lenta e gradual da recessão de 2014 a 2016, não tendo sido suficiente para recuperar as perdas observadas no período recessivo. Seus graves problemas fiscais se agravaram com a chegada da pandemia ao país em decorrência da perda de receitas fiscais e aumento de despesas, especialmente por conta da criação do auxílio emergencial a trabalhadores informais e beneficiários do Bolsa Família, como forma de amenizar os impactos econômicos da pandemia na vida de dezenas de milhóes de pessoas.

Embora o isolamento social tenha se iniciado no país em meados de março, ${ }^{6}$ afetando, portanto, diretamente apenas quinze dias do primeiro trimestre do ano, esse curto período de tempo já foi suficiente para que o PIB desse trimestre se reduzisse em 1,5\%, de acordo com as Contas Nacionais Trimestrais (CNT) do Instituto Brasileiro de Geografia e Estatística (IBGE). Por essa razão, as estimativas do desempenho econômico brasileiro para o primeiro semestre do ano apontam uma forte perda acumulada do PIB, inclusive maior que qualquer outra recessão já vivenciada no país.

3. Segundo Eichenbaum, Rebelo e Trabandt (2020), a epidemia tem efeitos na demanda e na oferta agregada independentemente da adoção das medidas de isolamento social. 0 risco de contaminação já faz com que as pessoas reajam de forma a reduzir sua exposição ao trabalho e ao consumo, o que gera efeitos recessivos nas economias. Por essa razão, embora haja um custo econômico ainda maior no fechamento temporário de atividades, é melhor fazê-lo para que os efeitos recessivos sejam concentrados apenas no curto prazo. Os autores ainda ressaltam que as medidas de isolamento social são a única maneira possível, atualmente, de evitar a perda de centenas de milhares de vidas, e não adotá-las geraria o aumento do número de mortes a ponto de cancelar os benefícios econômicos esperados da não intervenção.

4. Os Estados Unidos, por exemplo, apresentaram retração de 9,5\% do produto interno bruto (PIB) no segundo trimestre de 2020, enquanto a perda acumulada em todo o período recessivo da crise financeira internacional (primeiro trimestre de 2008 ao segundo trimestre de 2009) foi de $4,0 \%$, segundo dados do Bureau of Economic Analysis (BEA).

5. De acordo com a hipótese considerada pelo Banco Mundial de que a atual recessão mundial terminará no quarto trimestre de 2020 e terá acarretado perda do PIB per capita mundial de 6,2\%.

6. As medidas de distanciamento social foram adotadas de forma descentralizada após a OMS ter elevado o estado de contaminação de Covid-19, em 11 de março. Por essa razão, as medidas foram adotadas em momentos e graus diferentes de restrição, a depender das definições dos governos estaduais e municipais de cada localidade, conforme a evolução da doença em seus territórios (Moraes, 2020). 
A partir da compilação de diversos dados disponíveis para o primeiro semestre de 2020, apresentam-se neste texto os efeitos imediatos da pandemia de Covid-19 sobre os agregados macroeconômicos brasileiros e a forma como as relaçóes comerciais brasileiras foram afetadas, visto que o contexto atual é de globalização. Apesar de diversas outras pandemias terem acontecido na história do mundo, não havia ocorrido ainda impacto tão severo na economia mundial em uma era em que as economias dos países estão mais interconectadas. Além disso, esta é a primeira recessão mundial decorrente exclusivamente de uma pandemia e das medidas para contê-la (World Bank, 2020). A partir da análise desses resultados, a ideia é compreender a magnitude do impacto da pandemia nos agregados macroeconômicos de oferta e demanda e nas relaçôes comerciais do Brasil com o mundo.

\section{BREVE EXPOSIÇÃO SOBRE OS AGREGADOS MACROECONÔMICOS DE OFERTA E DEMANDA}

O Sistema de Contas Nacionais (SCN) tem o objetivo de retratar a dinâmica econômica de um país, sendo uma de suas funçóes identificar a origem dos recursos produtivos e a sua utilização pelos agentes da economia, mostrando a inter-relação entre os fluxos de oferta e demanda de produtos. O IBGE é o órgão oficial responsável por produzir essas informações para a economia brasileira.

Em virtude da necessidade de compilação de uma ampla gama de informaçóes e tratamento meticuloso realizado pelo IBGE, a última informação completa ${ }^{7}$ disponível do SCN do Brasil é de 2017. Embora, em condiçôes normais, a defasagem de dois anos náo comprometa a análise da composição da economia no longo prazo, o atual momento vivenciado no contexto da pandemia de Covid-19 traz inúmeras incertezas a respeito de como a estrutura econômica está sendo impactada.

A peculiaridade desse cenário, com impactos negativos sem precedentes em diversos agregados macroeconômicos, traz à tona, portanto, a necessidade de compreender as mudanças que estáo ocorrendo no curto prazo. Por essa razão, o objetivo deste trabalho é antecipar o comportamento de uma parte das informaçóes produzidas pelo IBGE de forma a analisar como os fluxos entre oferta e demanda de produtos da economia brasileira estão reagindo aos efeitos da pandemia e como isso influencia a composição dos agregados macroeconômicos. Para tal, foram estimados indicadores mensais, a preços constantes, para nove agregados macroeconômicos que compóem a oferta total e a demanda total. No quadro 1 apresentam-se os indicadores. ${ }^{8}$

As informaçóes do quadro 1 mostram, na tabela de recursos, os componentes da oferta da economia a preços do consumidor (oferta total) indicando como são originados os recursos oferecidos na economia, seja pela produção nacional ou pela importaçáo de produtos adicionando-se os impostos líquidos de subsídios a produtos e as margens de comércio e de transporte. ${ }^{9} \mathrm{Na}$ tabela de usos são

\footnotetext{
7. De acordo com IBGE (2016), a informação completa do SCN é composta por cinco blocos: i) Contas Econômicas Integradas (CEI), nas quais se apresenta todo o conjunto de contas dos setores institucionais e do resto do mundo; ii) Tabelas de Recursos e Usos (TRU), que agrupam as atividades econômicas e os produtos de acordo com o tipo de transação econômica e os componentes do valor adicionado; iii) tabela tridimensional das transações financeiras e dos estoques de ativos e passivos financeiros, na qual estão diretamente representadas as relações entre os setores institucionais; iv) tabela na qual algumas transações dos setores institucionais são apresentadas de acordo com sua função; e v) tabelas de população e emprego.

8. Para mais informações sobre a elaboração dos indicadores, ver o apêndice.

9. Como a estimação foi realizada apenas para o total de produtos, não foi necessário avaliar as margens, uma vez que elas incidem apenas na oferta a preços do consumidor em nível individual e são anuladas na análise da economia total.
} 
apresentados como os produtos ofertados na economia são utilizados, seja pela demanda externa (exportaçôes), consumo final (famílias + governo), FBC (investimento) ou consumo intermediário, que é a utilizaçáo de insumos no processo produtivo da economia nacional. O somatório da oferta total deve ser equivalente ao da demanda total.

QUADRO 1

Agregados macroeconômicos estimados até o primeiro semestre de 2020

\begin{tabular}{|l|l|}
\hline \multicolumn{1}{|c|}{ TABELA DE RECURS0S } & \multicolumn{1}{c|}{ TABELA DE USOS } \\
\hline Oferta a preços do consumidor (A) $=\mathrm{A} 1+\mathrm{A} 2+\mathrm{A3}$ & Demanda total $(\mathrm{A})=\mathrm{B} 1+\mathrm{B} 2.1+\mathrm{B2} .2+\mathrm{B2} .3$ \\
\hline Impostos líquidos de subsídios a produtos (A3) & Consumo intermediário (B1) \\
& Consumo final (B2.1) \\
Produção (A1) & Formação bruta de capital (FBC) (B2.2) \\
Importação (A2) & Exportações (B2.3) \\
\hline
\end{tabular}

Fonte: IBGE, SCN e TRU.

Elaboração da autora.

É importante salientar que o esforço empregado para a estimação tempestiva desses indicadores foi feito com o intuito de dimensionar os efeitos da pandemia sobre a economia nacional, e náo a mensuraçáo exata que será realizada pelo IBGE por meio de um conjunto de informaçóes mais amplo e robusto do que o que foi compilado para este estudo.

\section{ANÁLISE DOS IMPACTOS DA PANDEMIA NOS AGREGADOS MACROECONÔMICOS BRASILEIROS}

A retração esperada, até o momento, para a economia brasileira em 2020 é a maior de toda a série histórica documentada para o país. ${ }^{10}$ De acordo com o último Boletim Focus do Banco Central do Brasil (BCB), ${ }^{11}$ até a conclusão deste trabalho, a mediana das expectativas apontava retração de $5,8 \%$ do PIB brasileiro neste ano. Além da expressiva queda, esse resultado traz inúmeras particularidades com relaçáo ao caráter da crise atual em decorrência da pandemia de Covid-19. A análise dos resultados estimados para o primeiro semestre de 2020 mostra que todos os principais agregados da oferta e da demanda da economia brasileira se retraíram neste período.

O resultado apresentado no gráfico 1 não tem precedentes na economia brasileira na análise da série iniciada em 1999. Mesmo para os anos de 2009 e 2016, que apresentaram resultados negativos para a maior parte dos componentes da oferta e da demanda, houve crescimento real dos componentes de consumo final e de exportação, respectivamente. A crise de 2009, motivada pela crise internacional do subprime, não transbordou de maneira tão intensa na absorção doméstica brasileira. Em 2016, o Brasil estava em recessão em consequência de problemas internos, principalmente, sem ter comprometimento da demanda externa (Balassiano, 2018). O panorama da atual crise é, portanto, mais grave em termos econômicos que o das recessôes anteriores vivenciadas pelo Brasil, pois, além de ser uma crise de escala mundial, ocorre concomitantemente a um momento em que o país ainda náo conseguiu resolver seus problemas internos, que se agravaram durante a pandemia.

10. A maior queda já registrada no PIB brasileiro foi de $-4,3 \%$ em 1981 e 1990, de acordo com o IBGE.

11. Divulgado em 24 de julho. 


\section{GRÁFICO 1}

Desempenho real dos agregados macroeconômicos brasileiros no primeiro semestre de 2020 (em comparação com o primeiro semestre de 2019)

(Em \%)

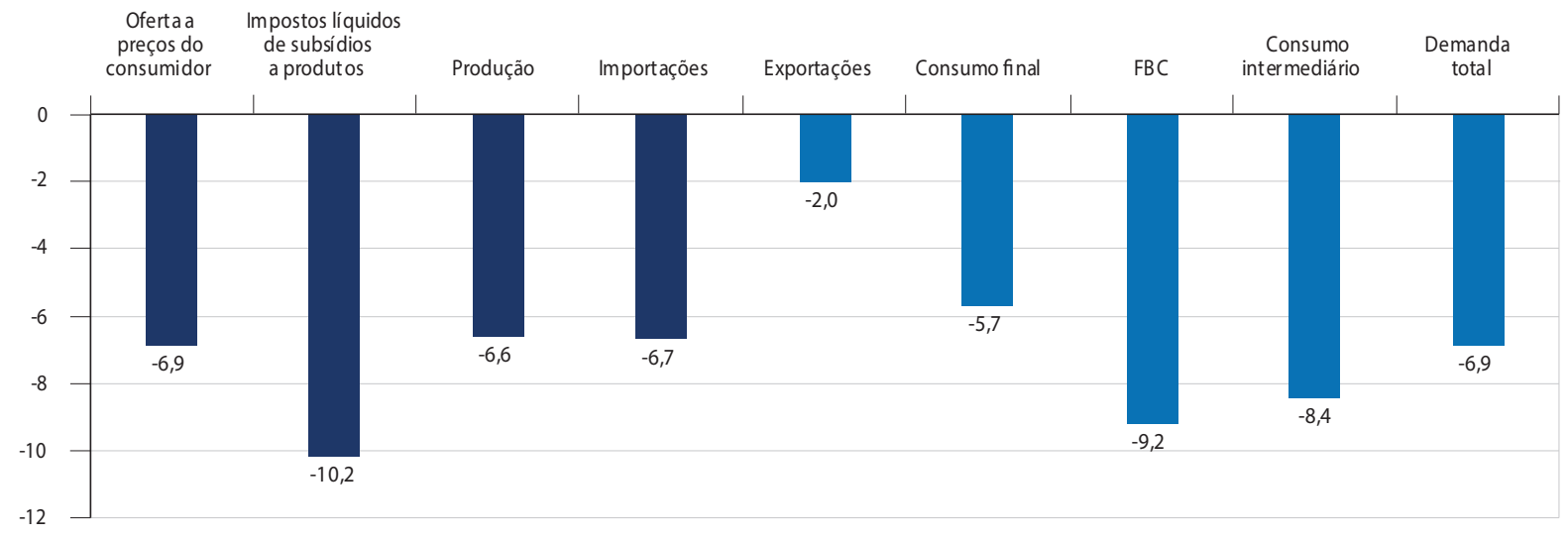

Fonte: IBGE, SECEX, Departamento de Informática do Sistema Único de Saúde (DataSUS), BCB, Agência Nacional do Petróleo, Gás Natural e Biocombustíveis (ANP), Empresa de Pesquisa Energética (EPE) e FGV.

Elaboração da autora.

Apesar de o primeiro caso de Covid-19 ter sido confirmado no país em 26 de fevereiro deste ano, de acordo com o Ministério da Saúde, os efeitos mais severos da pandemia na economia começaram a ser sentidos a partir de março, quando iniciou-se a adoção das medidas de isolamento social. Para fins de análise, os resultados do primeiro semestre deste ano foram desagregados em dois períodos de forma a entender como a economia brasileira se comportou no início de 2020: período pré-Covid-19 (de janeiro a fevereiro) e período com Covid-19 (de março a junho).

\section{GRÁFICO 2}

Desempenho real dos agregados macroeconômicos brasileiros no primeiro semestre de 2020: período pré-Covid-19 e período com Covid-19 (em comparação com os mesmos períodos de 2019) (Em \%)

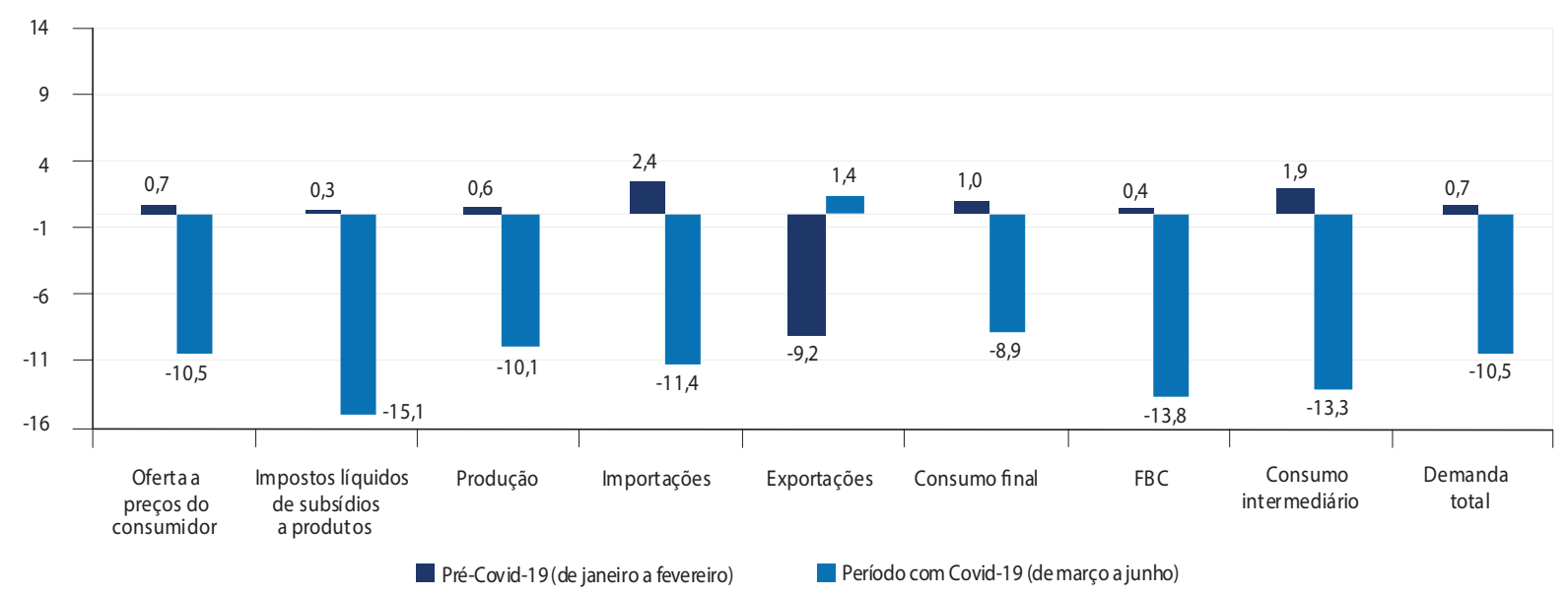

Fonte: IBGE, SECEX, DataSUS, BCB, ANP, EPE e FGV.

Elaboração da autora.

No período definido como pré-Covid-19, todos os componentes da oferta e da demanda apresentaram crescimento interanual, à exceção do volume exportado, que recuou 9,2\%. No período com Covid-19, 
que contabiliza os meses de março a junho, o desempenho dos agregados macroeconômicos revelou uma inversão nas variações apresentadas no primeiro bimestre, indicando os primeiros impactos diretos da pandemia nos agregados macroeconômicos brasileiros de fluxo de oferta e demanda. As exportaçóes foram o único agregado a apresentar crescimento nesse período, em volume, tendo sido impulsionadas por uma forte expansão das exportaçôes de produtos agropecuários, com destaque para o comércio com os países asiáticos, segundo dados do Indicador de Comércio Exterior (ICOMEX) da FGV.

Com esses resultados, a contribuição do volume das exportaçóes líquidas (diferença entre exportaçóes e importaçóes) para o desempenho da economia brasileira, que havia sido negativa no primeiro bimestre do ano, passou a ser positiva em 0,7 ponto percentual (p.p.) no acumulado do primeiro semestre, quando incorporado o período com Covid-19, conforme apresentado no gráfico 3. A despeito disso, os indicadores estimados neste trabalho apontam retração de $5,7 \%$ do PIB no primeiro semestre deste ano, em comparação com o primeiro semestre de 2019.

\section{GRÁFICO 3}

Contribuição das exportações líquidas para o desempenho interanual real do PIB brasileiro no primeiro semestre de 2020

(Em p.p.)

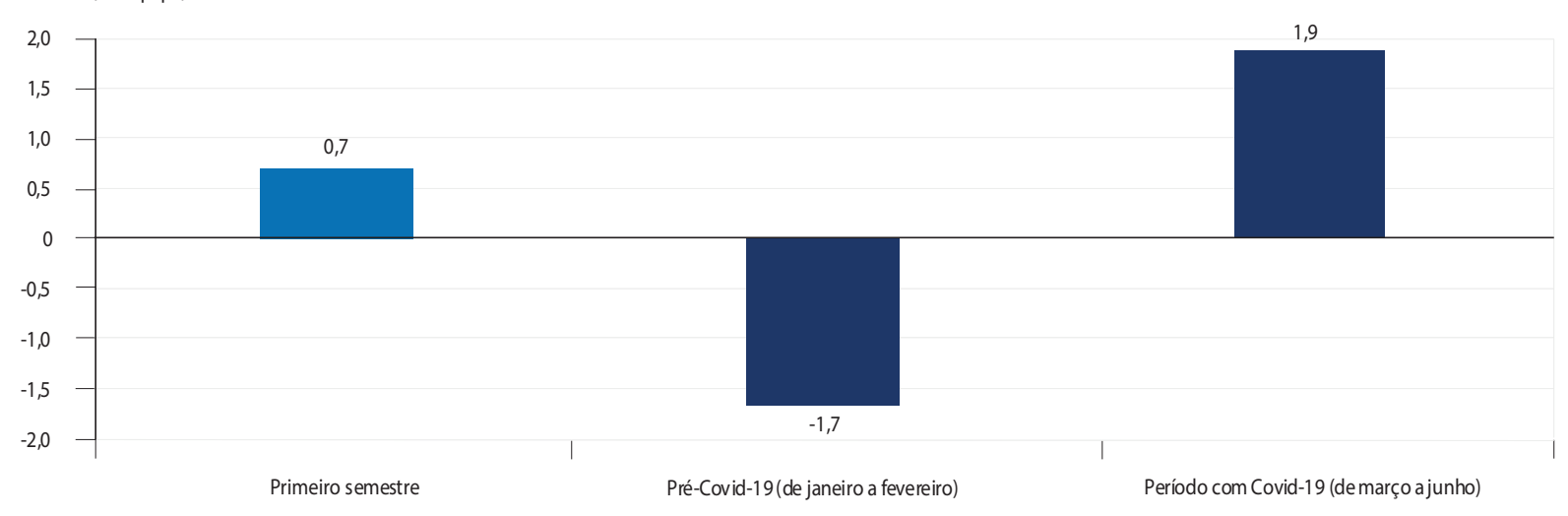

Fonte: IBGE, SECEX, DataSUS, BCB, ANP, EPE e FGV.

Elaboração da autora.

Apesar de o resultado semestral revelar uma forte retração, a análise mensal dos resultados do primeiro semestre, na série livre de efeitos sazonais, mostra que o pior momento para a economia brasileira, após a chegada da pandemia no primeiro trimestre, foi o mês de abril. As informaçóes de maio e junho já indicam crescimento na margem dos indicadores, tanto na análise desagregada da oferta quanto na análise da demanda. Os gráficos 4 e 5 apresentam as variaçóes mensais com relação aos meses imediatamente anteriores, calculadas na série com ajuste sazonal para os componentes da oferta e da demanda, respectivamente.

Com base nesses dados, nota-se que, mesmo em fevereiro, momento antes da adoção das medidas de isolamento social no Brasil, os três componentes do fluxo de oferta de bens e serviços haviam se retraído e, pela ótica da demanda total, apenas as exportaçóes tinham crescido com relaçáo a janeiro. Após três meses consecutivos de quedas, a oferta total, e consequentemente o total da demanda, voltou a crescer a partir de maio. $\mathrm{O}$ mês de abril registrou náo apenas a maior retraçáo da oferta e da demanda brasileira da pandemia de Covid-19, mas também de toda a série histórica desde 1998; a retração de $-11,7 \%$ no mês superou a maior queda da série até então, que havia sido em maio de 2018 (-6,5\%), quando ocorreu a greve dos caminhoneiros no país. 


\section{GRÁFICO 4}

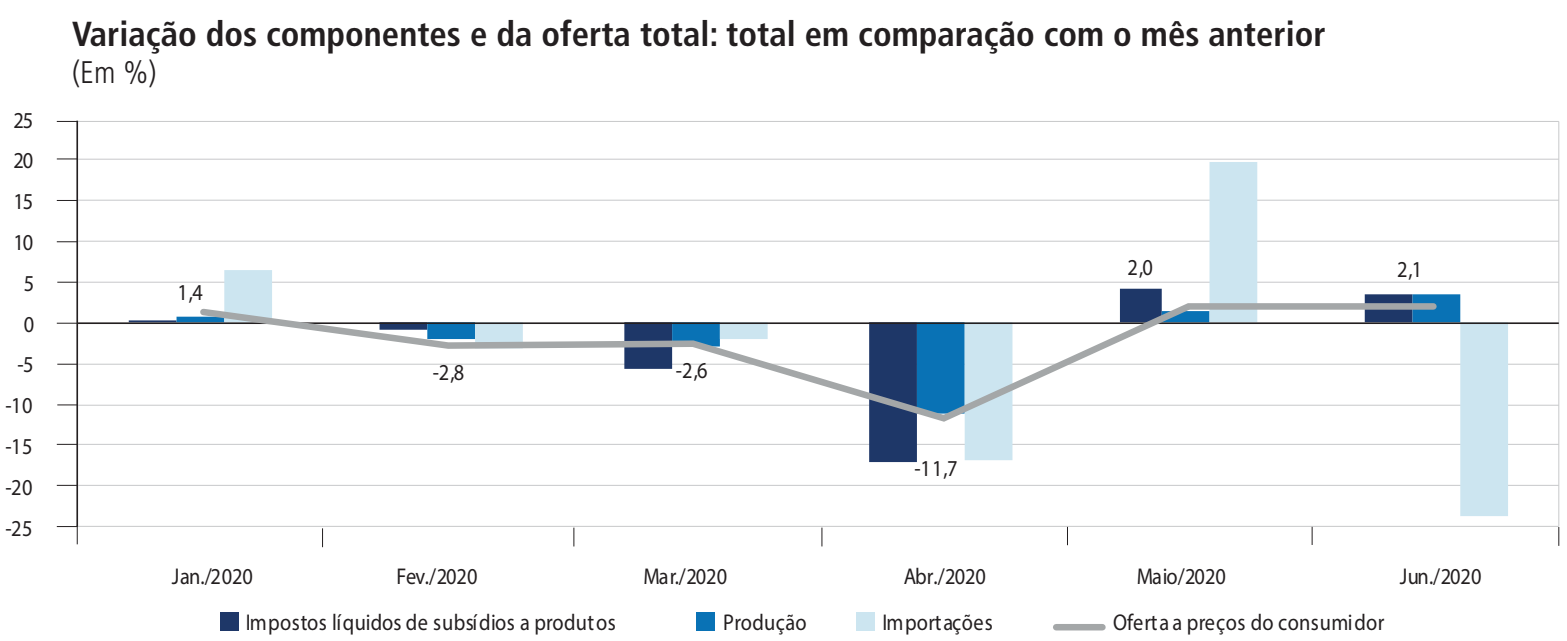

Fonte: IBGE, SECEX, DataSUS, BCB, ANP, EPE e FGV.

Elaboração da autora.

\section{GRÁFICO 5}

Variação dos componentes e da demanda total: total em comparação com o mês anterior (Em \%)

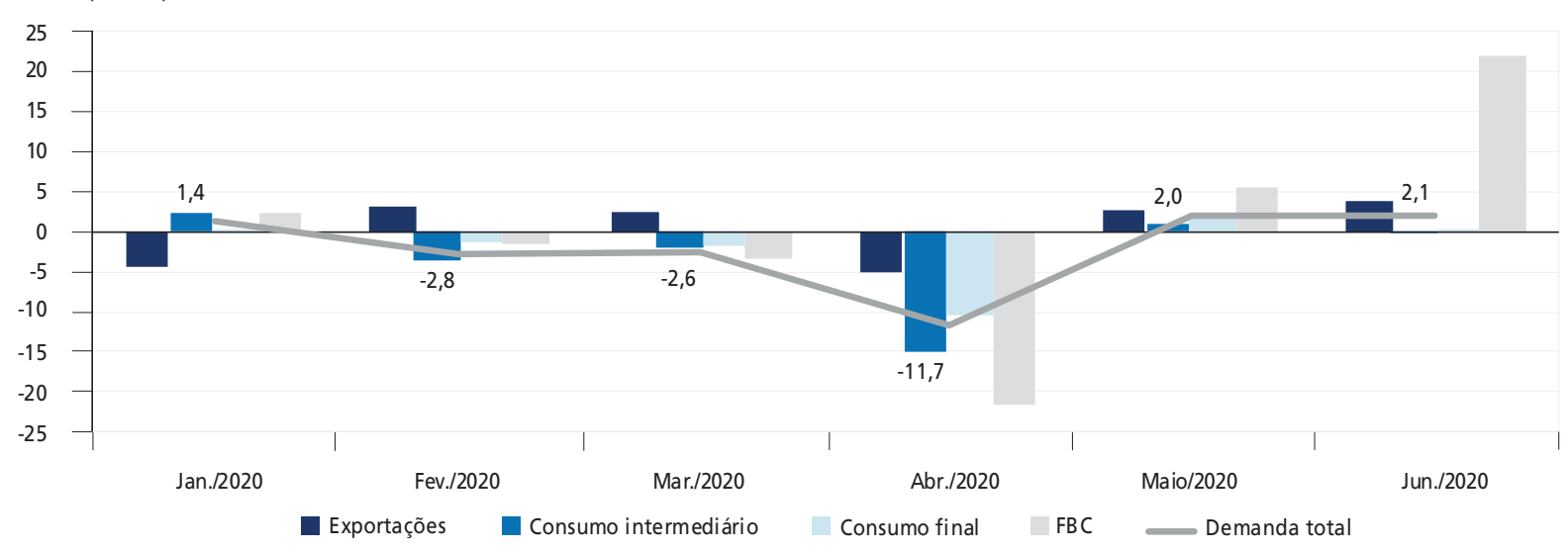

Fonte: IBGE, SECEX, DataSUS, BCB, ANP, EPE e FGV.

Elaboração da autora.

Apesar de os primeiros impactos severos da pandemia na economia brasileira terem aparentemente ocorrido até abril, os crescimentos observados em maio e junho não foram suficientes para que os agregados macroeconômicos retornassem ao patamar alcançado antes da chegada do vírus no país. Cabe destacar que o crescimento elevado e a consequente queda acentuada do volume de importaçóes em maio e junho, respectivamente, aconteceram em razão da importação de plataformas de petróleo que também impactaram a FBC do país. As fortes oscilaçóes desses agregados em maio e junho, portanto, não devem ser inteiramente relacionadas aos efeitos da pandemia.

Para a maioria dos componentes da oferta e da demanda, os crescimentos observados em maio e junho atenuaram as enormes perdas ocorridas de fevereiro a abril, sendo as únicas exceçóes, pela ótica da oferta total, as importaçóes, e pela ótica da demanda total, as exportaçóes, que haviam crescido em fevereiro e março. 
De acordo com o gráfico 6, a perda acumulada das importaçóes aumentou quando se analisa o período de fevereiro a junho com relação ao de fevereiro a abril. A desvalorizaçáo do real, que encareceu os produtos importados no mercado interno, em conjunto com o aumento da incerteza e com o adiamento de decisōes de investimento e de consumo resultaram na ampliação da retração das importaçóes no período. Por sua vez, as exportaçóes, que se mantiveram praticamente estagnadas entre fevereiro e abril, apresentaram crescimento significativo quando se analisa o período de fevereiro a junho, sendo o único componente do fluxo de demanda de bens e serviços a demonstrar crescimento no período analisado, sinalizando que superou o patamar registrado em janeiro deste ano. Embora as exportaçôes brasileiras tenham diminuído para alguns importantes parceiros comerciais no período, como a Argentina e a União Europeia, revelaram expressivo aumento para a Ásia, com destaque para a China, que sustentou as exportaçóes brasileiras no período, de acordo com o ICOMEX. A China, que já havia começado o processo de flexibilização do isolamento durante esse período, teve papel relevante na elevação das exportaçóes brasileiras, ressaltando os produtos agropecuários.

\section{GRÁFICO 6}

Variações acumuladas no primeiro semestre de 2020 por período após a chegada da pandemia de Covid-19 no Brasil

(Em \%)

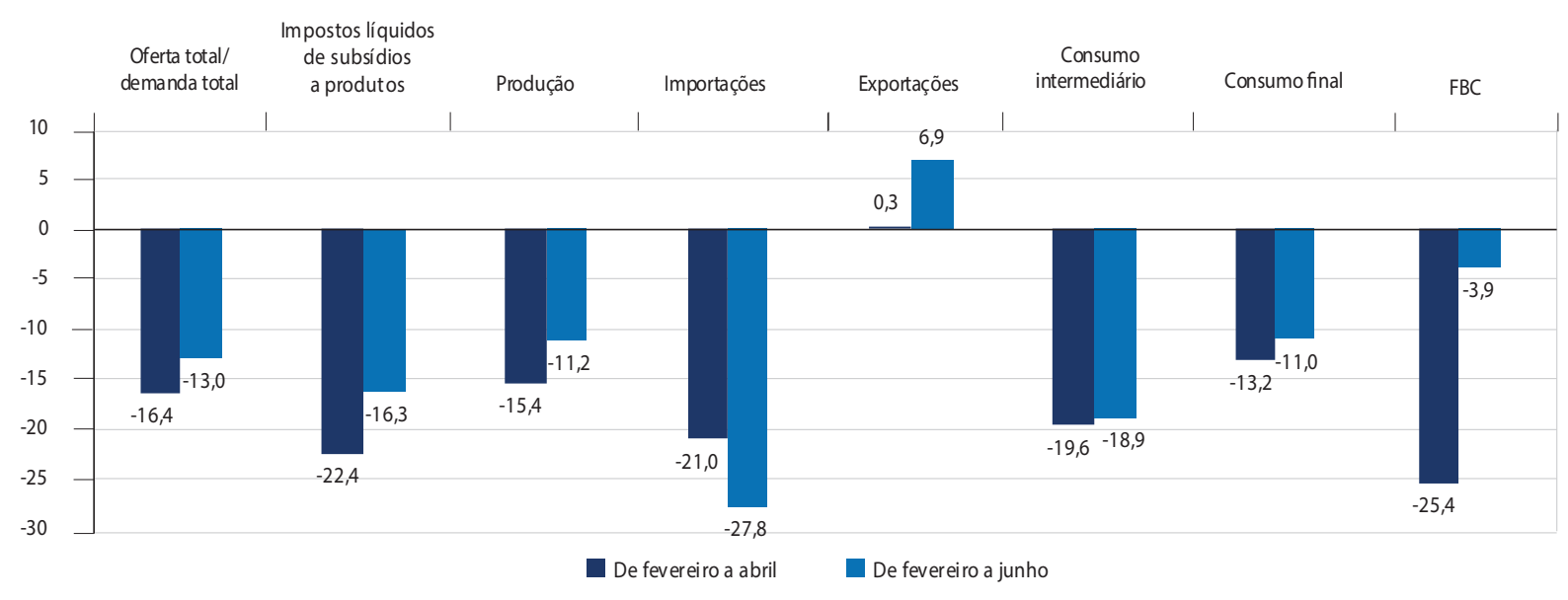

Fonte: IBGE, SECEX, DataSUS, BCB, ANP, EPE e FGV.

Elaboração da autora.

Em termos estruturais, embora as fortes retraçóes no primeiro semestre tenham sido percebidas em diversos agregados macroeconômicos, a heterogeneidade das variações pode estar acelerando um processo de modificação da composição desses agregados brasileiros que já vinha ocorrendo antes da chegada da pandemia ao país.

Desde 2004 nota-se que a demanda final, composta pela demanda externa (exportações) e pela demanda interna (consumo final e FBC), tem aumentado sua participação no total da demanda (demanda final + consumo intermediário) brasileira a preços constantes, o que se acelerou no primeiro semestre deste ano. Consequentemente, houve uma perda de participação do consumo intermediário ${ }^{12}$ na demanda total. A FBC (investimentos) também tem apresentado redução de participação na

12. O consumo intermediário representa os insumos que são utilizados no processo produtivo do país. 
demanda total, com recuo de 5,2 p.p. de 2013 a 2016. Ainda que tenha apresentado pequena melhora nos anos posteriores, voltou a declinar no primeiro semestre de 2020 com a chegada da pandemia.

As reduçôes da participação dos investimentos e do consumo intermediário na demanda total podem sinalizar uma perda da capacidade produtiva brasileira, que se ampliou com a chegada da pandemia de Covid-19. No primeiro semestre de 2020, pela primeira vez, a representatividade conjunta desses dois agregados foi menor que 50\%, conforme apresentado no gráfico 7 .

\section{GRÁFICO 7}

Participação conjunta do consumo intermediário e dos investimentos na demanda total da economia brasileira

(Em \%)

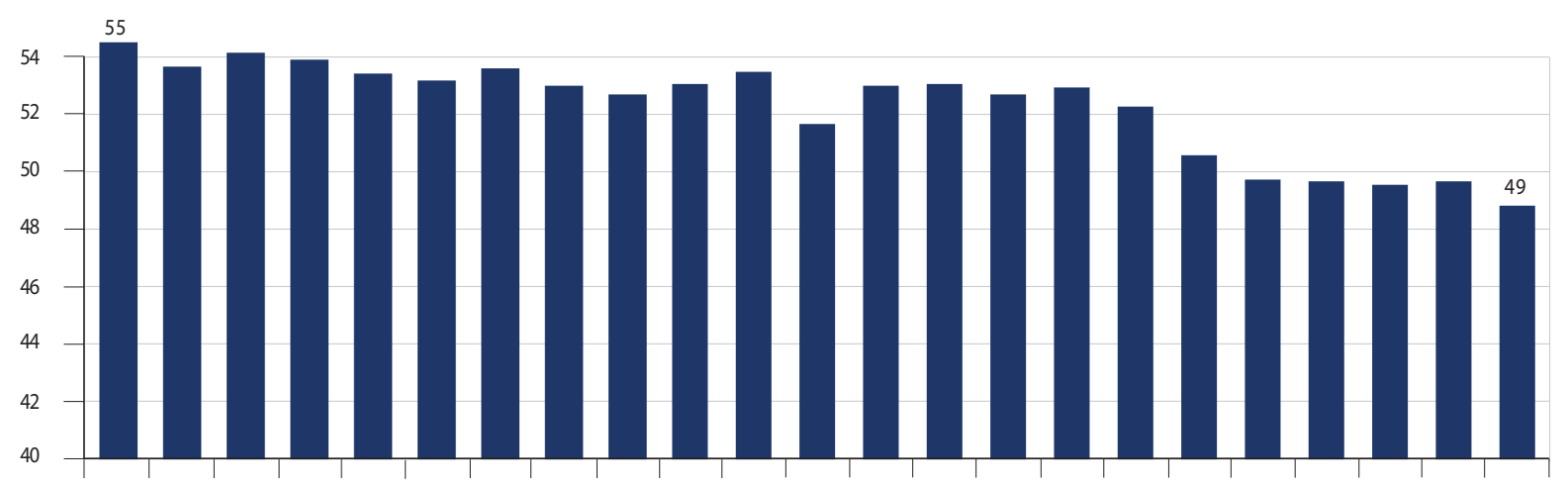

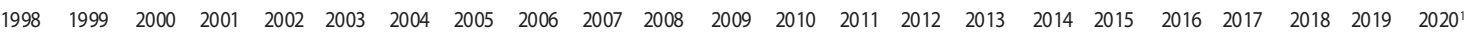

Fonte: IBGE, SECEX, DataSUS, BCB, ANP, EPE e FGV.

Elaboração da autora.

Nota: ${ }^{1}$ Primeiro semestre.

Mesmo que a economia tenha voltado a crescer a partir de maio, em termos marginais, as alteraçôes na composição da economia ao longo do tempo, a qual já apresentava fragilidades com relação à redução de participação dos agregados referentes ao processo produtivo, ficaram ainda mais comprometidas com a chegada da Covid-19 ao país. Esses resultados mostram que os efeitos negativos da pandemia sobre a economia brasileira podem perdurar por um longo tempo, tendo em vista que estão contribuindo para acelerar alteraçôes na estrutura econômica de forma a expor fragilidades do país.

\section{DESEMPENHO DO COMÉRCIO EXTERNO BRASILEIRO DURANTE A PANDEMIA DE COVID-19}

A análise dos fluxos de oferta e de demanda de bens e serviços além de dimensionar os impactos gerais na economia permite também mensurar a dependência econômica de um país em relaçáo ao comércio exterior. Com o avanço da globalização e a maior conexão entre os mercados globais, é fundamental entender essas relaçôes de forma a medir as fragilidades e os potenciais da economia nacional ante as relaçóes comerciais com o mundo. Em um período de turbulência mundial, como o atual gerado pela pandemia de Covid-19, torna-se ainda mais importante entender como as relaçôes comerciais estão sendo afetadas. Esta seção, que apresenta mais detalhadamente como as exportaçôes e as importaçôes brasileiras foram impactadas no primeiro semestre deste ano, está subdividida em 
duas partes. A primeira aborda os impactos da pandemia no coeficiente de penetração das importaçóes brasileiras, enquanto a segunda apresenta o desempenho do coeficiente das exportaçóes brasileiras.

\subsection{Coeficiente de penetração das importações brasileiras}

O coeficiente de penetração das importaçôes mede a dependência da economia nacional por produtos importados. O cálculo desse indicador foi realizado pela divisão do valor, a preços constantes, do volume de importaçóes em relação ao consumo aparente (somatório do que é produzido no país, adicionado ao que foi importado e excluído o que foi exportado).

Como apresentado no gráfico 8, no Brasil, o indicador cresceu significativamente entre 2005 e 2010 em virtude do fortalecimento do real, mantendo esse patamar até 2014, quando voltou a recuar a partir do aumento da taxa de câmbio e da entrada do país em recessão. A partir de 2017, quando a economia brasileira tornou a crescer, esse coeficiente se elevou novamente. No primeiro semestre de 2020, com o início de uma nova recessão por causa da pandemia, nota-se leve redução (-0,2 p.p.) do coeficiente de penetraçáo das importaçóes, embora a análise desagregada do indicador mostre elevação da penetraçáo das importaçóes dos produtos industriais (1,1 p.p.), indicando aumento da oferta de produtos industrializados importados na economia brasileira.

No gráfico 9, observa-se que o coeficiente de importaçôes dos produtos industriais é, historicamente, o de maior dependência do Brasil, e a chegada da pandemia intensificou a penetraçáo de importados industriais no país. Os produtos da indústria responsáveis pelo aumento desse coeficiente no primeiro semestre deste ano foram os da indústria de transformação.

\section{GRÁFICO 8}

Coeficiente de penetração das importações brasileiras (Em \%)

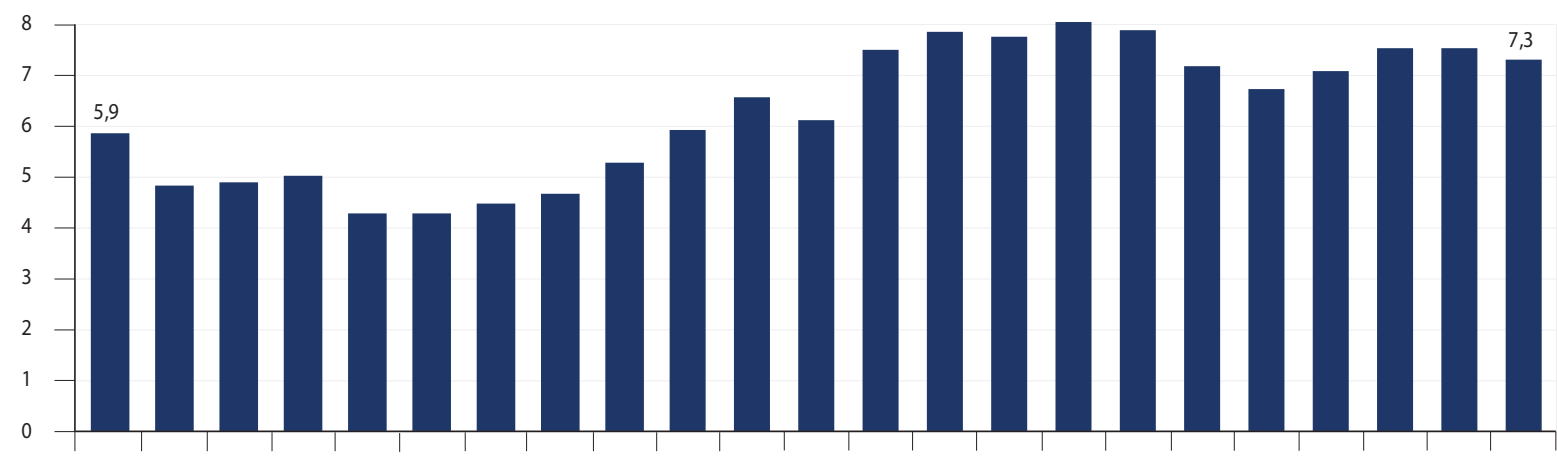

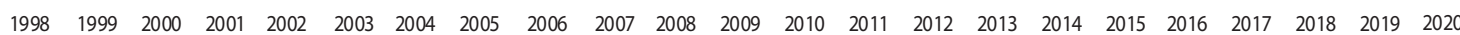

Fonte: IBGE e SECEX.

Elaboração da autora.

Nota: ${ }^{1}$ Primeiro semestre. 


\section{GRÁFICO 9}

\section{Coeficiente de penetração das importações brasileiras por segmento}

(Em \%)

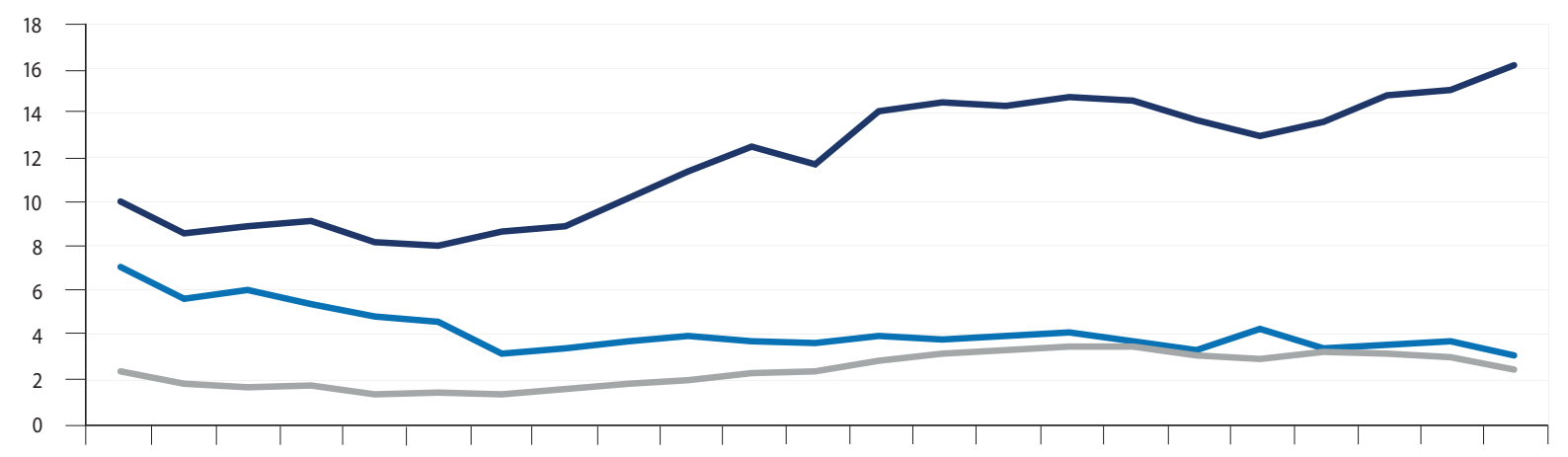

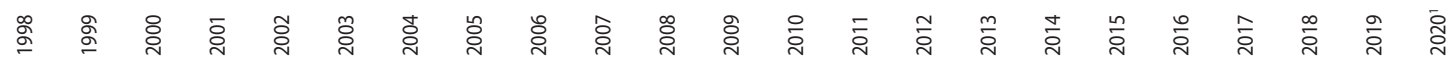 \\ Produtos industriais $\longrightarrow$ Produtos agropecuários $\quad$ Serviços}

Fonte: IBGE e SECEX.

Elaboração da autora.

Nota: ${ }^{1}$ Primeiro semestre.

$\mathrm{Na}$ análise desagregada dos coeficientes de penetração de importados da indústria de transformação, observa-se um aumento da intensidade dos grupos de produtos que já eram mais dependentes das importaçóes antes da chegada da pandemia. Em um total de treze grupos de produtos ${ }^{13}$ investigados, onze apresentaram ampliação do coeficiente de importação na economia brasileira no primeiro semestre deste ano com relação a 2019, sendo as únicas exceçóes o grupo de produtos de perfumaria, higiene e limpeza (-1,5 p.p.) e o de madeira, móveis e produtos diversos (-0,7 p.p.).

Apesar do aumento do coeficiente em vários grupos de produtos da indústria de transformação, quando se analisa o comportamento interanual das variáveis que compõem o coeficiente de penetração das importaçôes, nota-se que, na maior parte dos casos, a intensificação no primeiro semestre ocorreu pela forte redução do consumo aparente, e não pelo crescimento efetivo das importaçóes desses grupos de produtos. Em muitos casos, a importação apenas retraiu menos que o consumo aparente. De modo geral, embora o indicador tenha crescido, a principal razão não foi o aumento do volume importado pelo Brasil.

No gráfico 10, observa-se que apenas dois grupos de produtos da indústria de transformação apresentaram desempenho pior das importaçóes que o do consumo aparente, embora, em ambos os casos, tanto as importaçóes quanto o consumo aparente tenham se retraído. Os grupos de produtos foram perfumaria, higiene e limpeza, e celulose, produtos de papel, impressão e reprodução de gravaçóes.

13. Os grupos de produtos da transformação investigados são: i) alimentos, bebidas e produtos do fumo; ii) têxteis, vestuário, couros e calçados; iii) celulose, produtos de papel, impressão e reprodução de gravações; iv) refino de petróleo, coque e biocombustíveis; v) resinas, elastômeros, defensivos, desinfetantes e outros químicos; vi) perfumaria, higiene e limpeza; vii) produtos farmacêuticos; viii) cimento, borracha e plástico; ix) metalurgia; $x$ ) máquinas e equipamentos; $x i)$ automóveis, camionetas, caminhões e ônibus; xii) peças para veículos automotores e outros equipamentos de transporte; e xiii) madeira, móveis e produtos diversos. 
GRÁFICO 10

Variação interanual dos agregados macroeconômicos que compõem o coeficiente de penetração das importações de acordo com os grupos de produtos da transformação no primeiro semestre de 2020 $(\mathrm{Em} \%)$

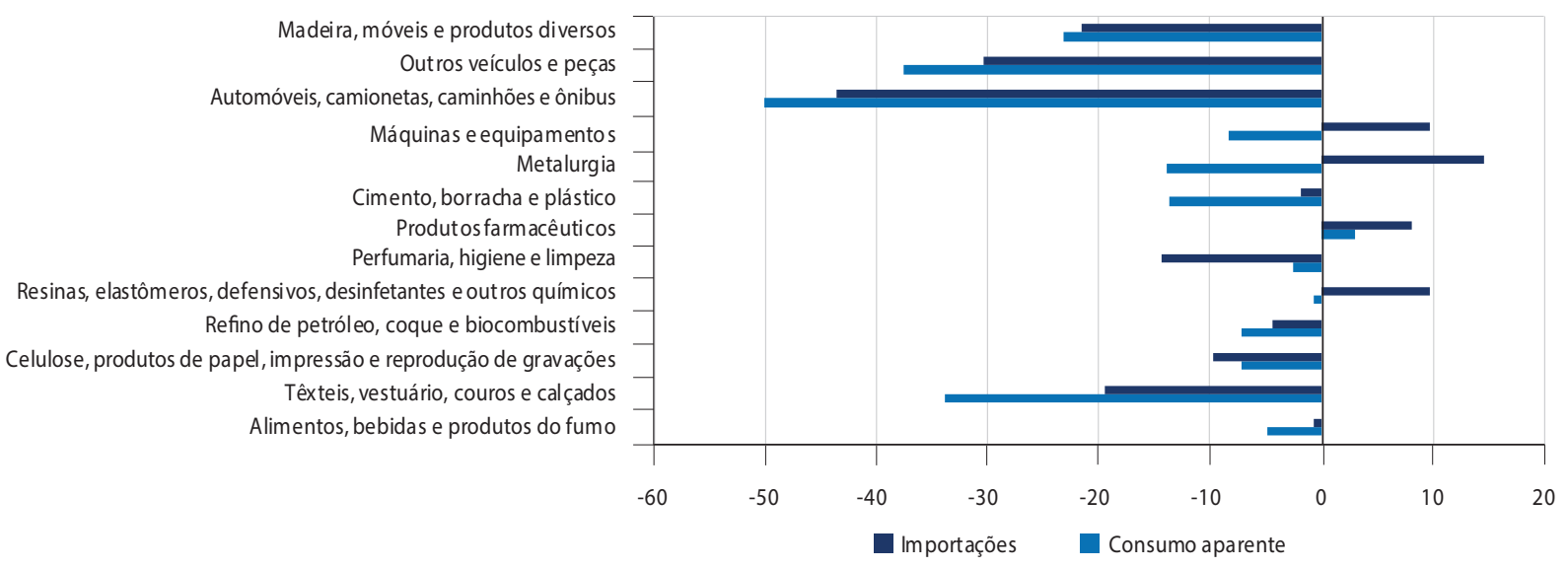

Fonte: IBGE, SECEX, DataSUS, BCB, ANP, EPE e FGV.

Elaboração da autora.

O grupo de produtos farmacêuticos também é alvo de destaque por ter sido o único a apresentar crescimento no consumo aparente e nas importaçôes no primeiro semestre do ano, o que é explicado pela essencialidade desse tipo de bem para a sociedade, ainda mais no contexto de uma pandemia. De qualquer forma, como o crescimento das importaçóes foi maior que o do consumo aparente, observou-se também uma intensificação das importaçóes nesse grupo de produtos no primeiro semestre de 2020 .

Outra forma de analisar o coeficiente de penetração de importações da indústria de transformação é pela desagregação em dois grandes grupos com características diferentes quanto ao perfil de importação. O primeiro grupo, denominado produtos com maior dependência das importaçôes, foi definido de acordo com dois critérios: $i$ ) ter coeficiente de penetraçáo das importaçóes acima de 15\% no primeiro semestre de 2020; e ii) ter apresentado crescimento do coeficiente de penetraçáo das importaçóes no primeiro semestre do ano. Dados esses critérios, seis grupos de produtos foram selecionados para compor este grupo: i) têxteis, vestuário, couros e calçados; ii) resinas, elastômeros, defensivos, desinfetantes e outros químicos; iii) farmacêuticos; iv) metalurgia; $v$ ) máquinas e equipamentos; $\mathrm{e}$ vi) peças e acessórios para veículos automotores e outros equipamentos de transporte. Os outros produtos foram alocados em demais grupos de produtos da transformação. No gráfico 11, apresenta-se a evolução dessas séries.

Nota-se que aqueles definidos como produtos com maior dependência das importaçóes apresentaram maior coeficiente de penetração das importaçôes em toda a série histórica, em comparação com os demais grupos de produtos da transformação, sendo que a amplitude entre os coeficientes desses grupos se elevou nos últimos três anos e chegou ao nível de 35\% no primeiro semestre de 2020, o maior de toda a série. Isso significa que $35 \%$ do que é ofertado internamente no Brasil, referente a esses grupos de produtos, é importado. A relevância da importaçáo desses produtos na demanda interna é de tal significado que mesmo o total das importaçóes brasileiras tendo se reduzido em $6,7 \%$ no primeiro semestre do ano, com relação ao primeiro semestre de 2019 , a importação desse segmento cresceu $4,4 \%$ no período. 
GRÁFICO 11

Coeficiente de penetração das importações por grupos de produtos do segmento da transformação (Em \%)

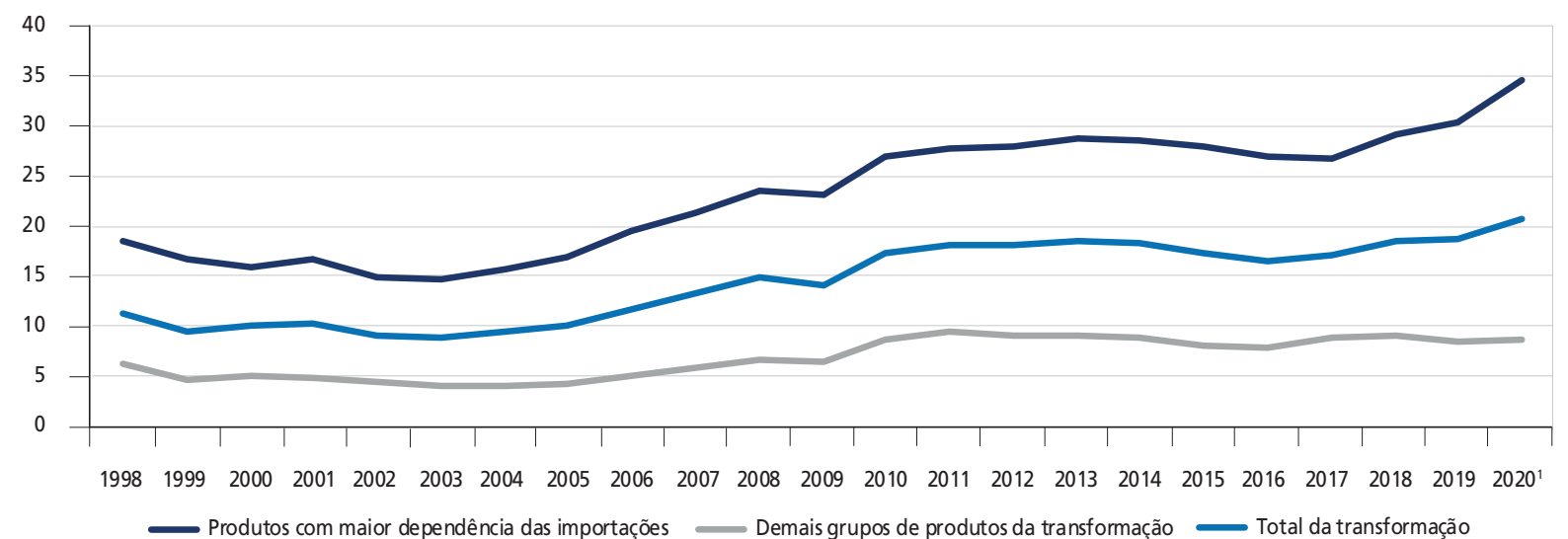

Fonte: IBGE, SECEX, DataSUS, BCB, ANP, EPE e FGV.

Elaboração da autora.

Nota: ${ }^{1}$ Primeiro semestre.

Em geral, o coeficiente de penetração das importaçôes mostrou uma intensificação da dependência interna por produtos importados característicos da transformação, a partir da chegada da pandemia de Covid-19 ao Brasil. Esse resultado mostra que, mesmo com as quedas registradas no volume importado por causa da alta do dólar no primeiro semestre, que encareceu tais produtos no mercado interno, houve redução da oferta interna de origem nacional ainda mais forte que a redução das importaçôes para esses produtos, evidenciando a fragilidade da indústria nacional diante da crise que se instalou no país este ano.

\subsection{Coeficiente das exportações brasileiras}

A análise da importância das exportações na produção nacional de um país pode ser medida pelo coeficiente de exportaçóes. O cálculo desse indicador, realizado neste trabalho a preços constantes, mede a participação das exportaçóes na produção nacional de forma a estimar quanto da produção doméstica transborda para o mercado externo.

No gráfico 12, nota-se que o indicador apresentou um pequeno aumento no Brasil, no primeiro semestre deste ano (0,3 p.p.). $\mathrm{Na}$ análise desagregada (gráfico 13), observa-se significativa expansão do coeficiente das exportaçóes de produtos agropecuários, desde 2009, alcançando o maior valor da série no primeiro semestre de 2020. O aumento do coeficiente de exportaçóes desse segmento e dos produtos industriais cresceu de forma semelhante no primeiro trimestre de 2020 (1,1 p.p.).

Apesar de a produção de produtos da agropecuária ter crescido 2,4\% no primeiro semestre de 2020, o aumento do volume exportado desses produtos foi aproximadamente dez vezes maior que o da produçáo nacional $(23,2 \%)$, o que resultou na forte elevação do coeficiente de exportaçáo dos produtos agropecuários. Segundo o relatório do ICOMEX, referente ao mês de junho, o segmento de produtos agropecuários foi o principal responsável pela dinâmica das exportaçôes brasileiras de bens, no primeiro semestre, liderados pelo complexo soja. 
GRÁFICO 12

Coeficiente de exportações brasileiro

(Em \%)

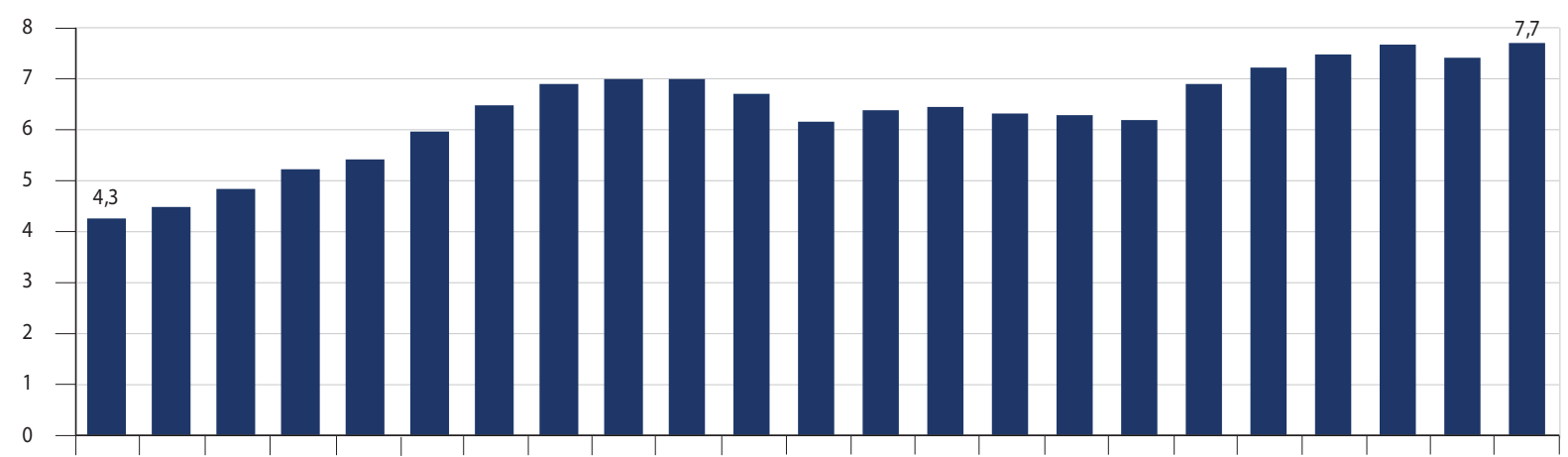

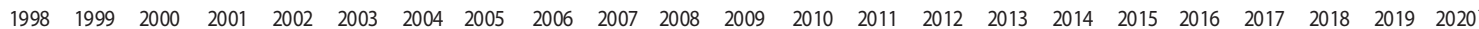

Fonte: IBGE e SECEX.

Elaboração da autora.

Nota: ${ }^{1}$ Primeiro semestre.

GRÁFICO 13

Coeficiente de exportações brasileiro por segmento

(Em \%)

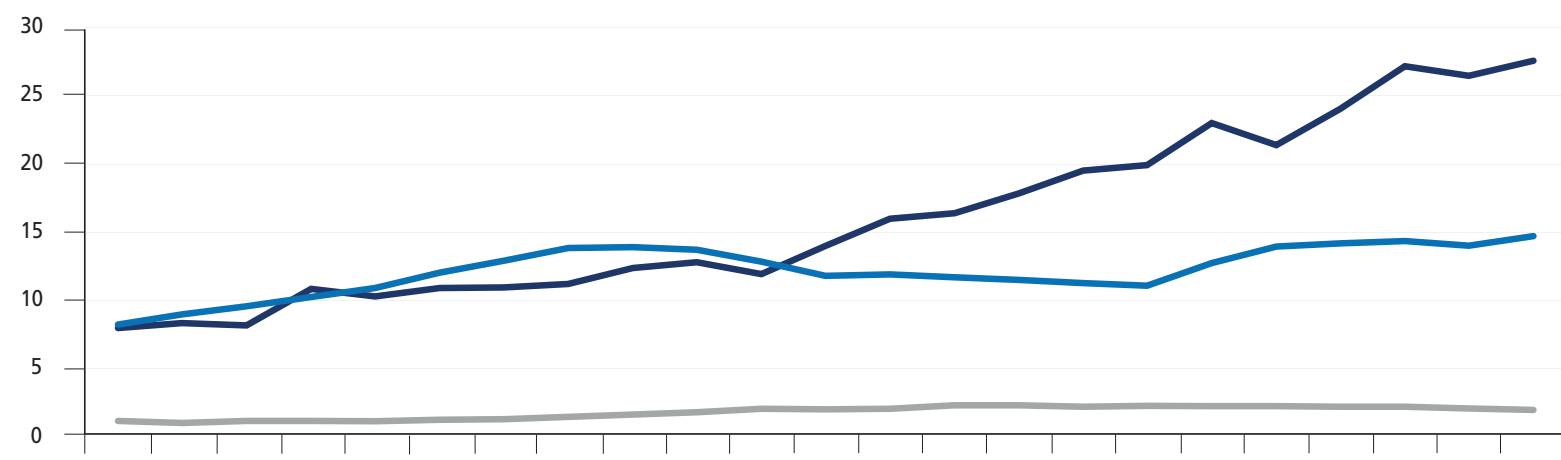

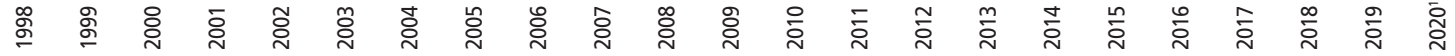

— Produtos agropecuários $\longrightarrow$ Produtos industriais $\longrightarrow$ Serviços

Fonte: IBGE e SECEX.

Elaboração da autora.

Nota: ${ }^{1}$ Primeiro semestre.

$\mathrm{Na}$ análise do coeficiente de exportação do segmento dos produtos industriais, destaca-se o desempenho dos produtos da extrativa mineral, com mais de $50 \%$ da produçáo nacional sendo destinada para a demanda externa, desde 2017. No primeiro semestre de 2020, o coeficiente de exportaçóes desse segmento manteve-se estável em 58\%, mesmo resultado de 2019. A elevaçáo do coeficiente de exportação de produtos industriais no primeiro semestre de 2020 ocorreu em virtude do aumento do coeficiente de exportaçôes da transformação.

$\mathrm{Na}$ análise desagregada da indústria de transformação por grupos de produtos, nota-se que houve crescimento do coeficiente de exportaçóes de nove grupos, dos treze investigados. Apesar disso, apenas em quatro casos essa elevação aconteceu devido a um aumento efetivo do volume 
exportado, conforme apresentado no gráfico 14 . Nos demais grupos de produtos com crescimento do coeficiente de exportaçôes, este ocorreu porque a redução da produção foi mais acentuada que a queda das exportaçóes desses grupos de produtos.

\section{GRÁFICO 14}

Variação interanual dos agregados macroeconômicos que compõem o coeficiente de exportações de acordo com os grupos de produtos da transformação no primeiro semestre de 2020 (Em \%)

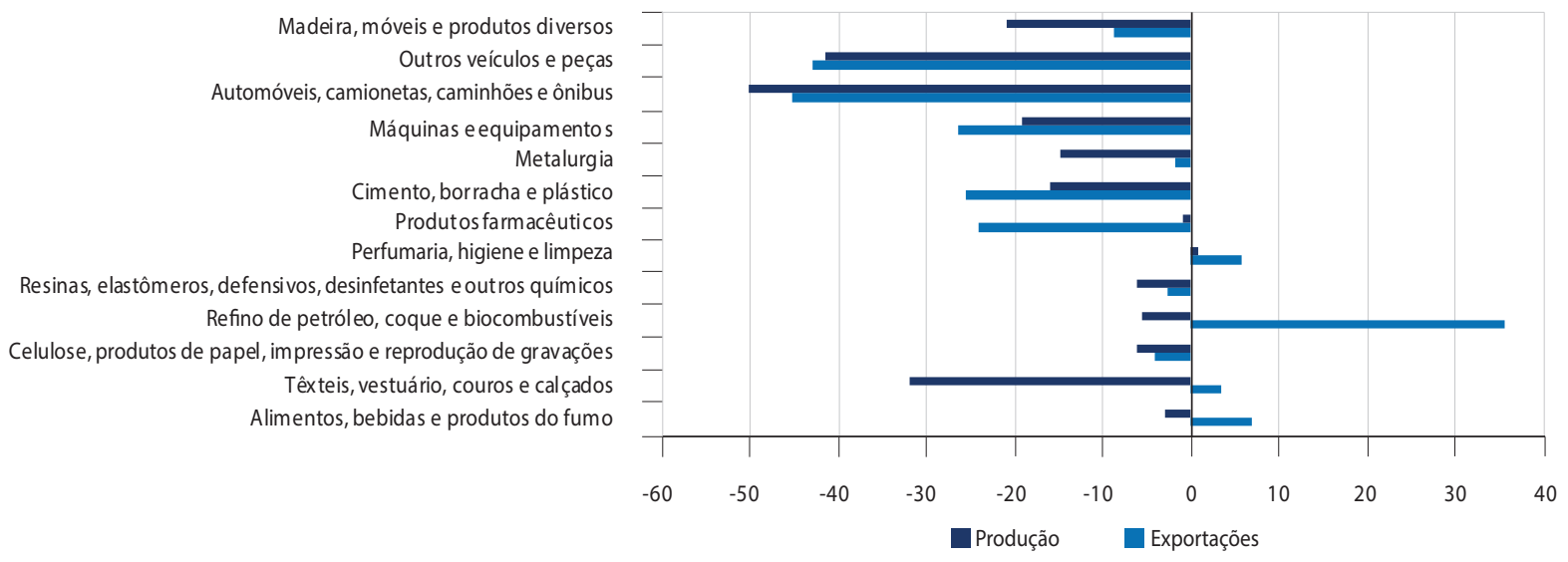

Fonte: IBGE, SECEX, DataSUS, BCB, ANP, EPE e FGV.

Elaboração da autora.

Destaca-se o expressivo aumento do volume exportado do grupo de produtos de refino de petróleo, coque e biocombustíveis, explicado pela elevada exportaçáo de petróleo da Petrobras no período. Segundo a empresa, apenas a China demandou $60 \%$ do total vendido. Outro ponto interessante é que, embora em percentual pequeno, apenas o grupo de produtos de perfumaria, higiene e limpeza apresentou crescimento da produção. O aumento da demanda por produtos de higiene, como álcool em gel, sabonetes e lenços de papel, caracterizados como "cesta Covid-19", explica o crescimento da produção desse grupo de produtos, que foi o único a registrar aumento tanto da produção quanto da exportação.

Assim como realizado na análise do coeficiente de penetração de importaçóes da indústria de transformação, o coeficiente de exportaçôes também foi desagregado em dois grandes grupos de produtos com características diferentes quanto ao perfil de exportação. O grupo denominado produtos com maior destinação ao mercado externo foi definido de acordo com dois critérios: i) ter coeficiente de exportaçôes acima de $15 \%$ no primeiro semestre de 2020; e ii) ter apresentado crescimento do coeficiente de exportaçóes no primeiro semestre do ano. A partir desses critérios, seis grupos de produtos foram selecionados: i) alimentos, bebidas e produtos do fumo; ii) têxteis, vestuário, couros e calçados; iii) celulose, produtos de papel, impressão e reprodução de gravaçôes; iv) metalurgia; $v$ ) automóveis, camionetas, caminhôes e ônibus; e vi) madeira, móveis e produtos diversos. Os outros produtos foram alocados em demais grupos de produtos da transformação. No gráfico 15, apresenta-se a evolução dessas séries.

Observa-se que a chegada da pandemia de Covid-19 apenas ampliou a diferença entre os coeficientes de exportaçôes dos dois grupos analisados, porém o grupo que apresentou aumento do coeficiente de exportaçóes no primeiro semestre deste ano já era o que tinha maior destinação da 
produção nacional para o mercado externo ao longo de toda a série histórica analisada. O coeficiente de exportaçóes deste grupo mostra que, no primeiro semestre de 2020, 22\% do volume de produtos produzidos por esse segmento destinou-se ao mercado externo, o maior percentual observado em toda a série histórica. A despeito de o volume total de exportaçóes da transformaçáo ter recuado $7,7 \%$ no primeiro semestre do ano, com relação ao primeiro semestre de 2019 , a retração do volume exportado do grupo produtos com maior destinação ao mercado externo foi significativamente menor $(-2,1 \%)$ que a dos demais grupos de produtos da transformação $(-18,1 \%)$, para o mesmo período.

GRÁFICO 15

Coeficiente de exportações por grupos de produtos do segmento da transformação (Em \%)

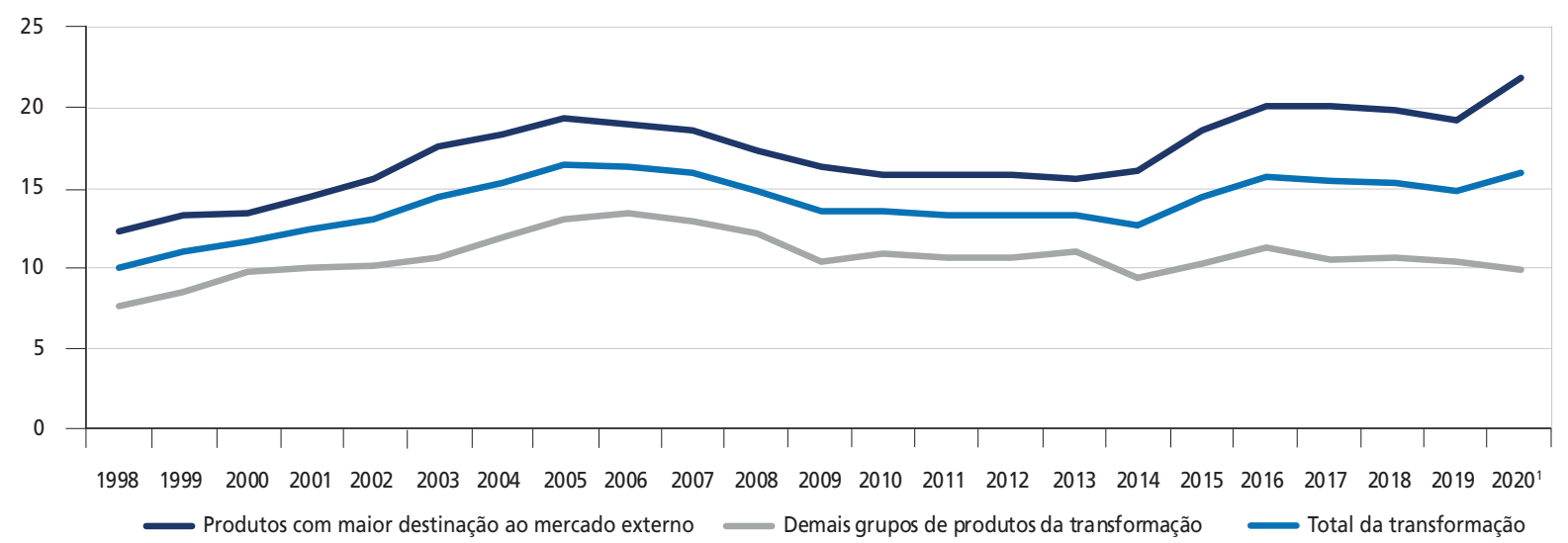

Fonte: IBGE, SECEX, DataSUS, BCB, ANP, EPE e FGV.

Elaboração da autora.

Nota: ${ }^{1}$ Primeiro semestre.

Esses resultados revelam que o aumento observado no coeficiente de exportaçóes dos produtos da transformação, com a chegada da pandemia, além de ter sido concentrado nos grupos de produtos que já tinham a maior parcela da produçáo destinada ao mercado externo, em comparaçáo com os outros produtos do segmento, ocorreu por uma retraçáo mais acentuada da produçáo nacional do que por um aumento efetivo do volume exportado, na maior parte dos casos.

\section{CONSIDERAÇÕES FINAIS}

Este artigo propôs investigar os primeiros impactos da chegada da pandemia de Covid-19 na economia brasileira. Por meio da atualização de agregados macroeconômicos de oferta e demanda com base em dados mensais disponíveis, analisou-se o comportamento desses agregados no período anterior e no período em que a Covid-19 já havia chegado ao país. Além disso, foram apresentadas possíveis alteraçóes na composição dos agregados macroeconômicos, pois, apesar de ser um período de tempo curto de análise, que geralmente não modifica tão rapidamente a estrutura econômica, elas já estavam em curso no país, e os severos impactos negativos da pandemia parecem ter intensificado essas alteraçóes.

A análise dos coeficientes de penetração das importaçôes, de forma a mensurar a dependência que a economia brasileira possui de produtos importados e como isso parece ter aumentado com a chegada da pandemia, indicou uma fragilidade da economia nacional, com a produçáo nacional 
tendo perdido espaço no mercado doméstico para as importaçóes, com destaque para os produtos industriais. Em um cenário de pandemia e recessão mundial, esse aumento da dependência do comércio exterior pode ser preocupante, caso novas ondas de contágio sejam observadas nos principais países fornecedores de produtos para o Brasil.

A análise do coeficiente de exportações também mostrou um aumento no primeiro trimestre de 2020, impulsionado pelo grupo de produtos agropecuários e da transformaçáo. Esse crescimento tem efeito positivo para o desempenho da economia brasileira, embora deva ser ressaltado que grande parte do aumento do coeficiente de exportaçôes dos produtos da indústria de transformação ocorreu por uma retração maior da produção no período do que por um efetivo crescimento das exportaçóes, que apresentou queda para diversos grupos de produtos no primeiro semestre de 2020. Esse resultado sugere que há uma redução maior no mercado interno que no mercado externo desses produtos.

Como a pandemia de Covid-19 ainda não foi controlada, a incerteza a respeito dos impactos futuros na economia ainda é muito elevada, embora não seja surpresa que os desafios a serem enfrentados no cenário pós-Covid-19 serão enormes, tendo em vista a magnitude das retraçóes experimentadas em diversos países na primeira metade do ano. No entanto, no caso brasileiro, os desafios econômicos já eram grandes mesmo antes da chegada da pandemia, com crescimento baixo, elevado desemprego e uma grave crise fiscal. A chegada da pandemia agravou ainda mais esse cenário, tornando-o mais desafiador mesmo após a extinção da Covid-19.

\section{REFERÊNCIAS}

BALASSIANO, M. Recessão brasileira (2014-2016): uma análise por meio do método do controle sintético do PIB, PIB per capita, taxa de investimento e taxa de desemprego. In: ENCONTRO NACIONAL DE ECONOMIA, 46., 2018. Anais... [s.l.]: ANPEC, 2018. Disponível em: <https://www.anpec.org.br/ encontro/2018/submissao/files_I/i4-e40f41cc1badaf4207dc9dc7f5823cc8.pdf>.

EICHENBAUM, M.; REBELO, S.; TRABANDT, M. The macroeconomics of epidemics. [s.l.]: NBER, Mar. 2020. Available at: <https://www.nber.org/papers/w26882>.

FGV - FUNDAÇÃO GETULIO VARGAS; IBRE - INSTITUTO BRASILEIRO DE ECONOMIA. Comunicado de dataçáo de ciclos mensais brasileiros: jun./2020 - CODACE. [s.l.]: FGV; IBRE, jun. 2020. Disponível em: <https://portalibre.fgv.br/node/1776>.

IBGE - INSTITUTO BRASILEIRO DE GEOGRAFIA E ESTATÍSTICA. Sistema de Contas Nacionais Brasil: ano de referência 2010. 3. ed. [s.l.]: IBGE, 2016. v. 24. Disponível em: <https://biblioteca.ibge.gov. $\mathrm{br} /$ visualizacao/livros/liv98142.pdf $>$.

IMF - INTERNATIONAL MONETARY FUND. World Economic Outlook: the great lockdown. Washington: IMF, Apr. 2020. Available at: <https://www.imf.org/en/publications/weo>.

MORAES, R. Medidas legais de incentivo ao distanciamento social: comparação das políticas e governos estaduais e prefeituras das capitais no Brasil. [s.l.]: Ipea, abr. 2020. (Nota Técnica, n. 16). Disponível em: $<$ https://www.ipea.gov.br/portal/index.php?option=com_content\&view=article\&id=35462\&Itemid=4>.

SEN-CROWE, B.; MCKENNEY, M.; ELKBULI, A. Social distancing during the COVID-19 pandemic: staying home save lives. The American Journal of Emergency Medicine, v. 38, n. 7, p. 1519-1520, Apr. 2020. Disponível em: <https://www.ajemjournal.com/article/S0735-6757(20)30221-7/fulltext>.

WORLD BANK. How deep will the COVID-19 recession be? In: WORLD BANK. Pandemic, recession: the global economy in crisis; global economic prospects. [s.l.]: World Bank, 2020. Available at: <https://www. worldbank.org/en/publication/global-economic-prospects>. 


\section{BIBLIOGRAFIA COMPLEMENTAR}

BRASIL. Ministério da Saúde. Brasil confirma primeiro caso da doença. [s.l.]: MS, fev. 2020. Disponível em: $<$ https://www.saude.gov.br/noticias/agencia-saude/46435-brasil-confirma-primeiro-caso-de-novo-coronavirus>. EUROPPEAN COMISSION et. al. System of National Accounts 2008. Nova York: Europpean Comission, 2009. Available at: <https://unstats.un.org/unsd/nationalaccount/sna2008.asp>.

FGV - FUNDAÇÁO GETULIO VARGAS; IBRE - INSTITUTO BRASILEIRO DE ECONOMIA. Relatório do ICOMEX. [s.l.]: FGV; IBRE, jul. 2020. Disponível em: <https://portalibre.fgv.br/node/1776>.

IBGE - INSTITUTO BRASILEIRO DE GEOGRAFIA E ESTATÍSTICA. Contas nacionais trimestrais: ano de referência 2010. 3. ed. [s.l.]: IBGE, 2016. v. 28. Disponível em: <https://www.ibge.gov.br/estatisticas/ economicas/contas-nacionais/9300-contas-nacionais-trimestrais.html?=\&t=downloads $>$.

WHO - WORLD HEALTH ORGANIZATION. Coronavirus disease (COVID-19): situation report 191. [s.l.]: WHO, jul. 2020. p. 7. Available at: <https://www.who.int/docs/default-source/coronaviruse/situationreports/20200729-covid-19-sitrep-191.pdf?sfvrsn=2c327e9e_2>. 


\section{APÊNDICE}

\section{PROCEDIMENTOS DE CÁLCULO DOS AGREGADOS MACROECONÔMICOS MENSAIS}

Para a elaboração da estimativa atualizada até o primeiro semestre de 2020 dos principais agregados macroeconômicos do Brasil, foram utilizadas as informaçôes oficiais do Sistema de Contas Nacionais (SCN) completo, de 1998 até 2017, os dados das Contas Nacionais Trimestrais (CNT), para as variaçóes anuais de 2018 e 2019 , além de diversos indicadores conjunturais mensais para o período recente. Os indicadores foram elaborados a preços constantes de 2017.

Para os indicadores de importaçóes e exportações foram utilizadas as informações da Secretaria de Comércio Exterior (SECEX) do Ministério da Economia e os dados do balanço de pagamentos disponibilizados pelo Banco Central. Para a estimativa do valor da produção e dos impostos líquidos de subsídios a produtos, foram utilizadas as pesquisas conjunturais do Instituto Brasileiro de Geografia e Estatística $\left(\mathrm{IBGE}^{1}\right.$ e de outras instituiçôes ${ }^{2}$ conforme metodologia das CNT, de maneira a estimar a evolução mensal dos agregados macroeconômicos das Tabelas de Recursos e Usos (TRU). ${ }^{3}$ Para a agregação dos dados de impostos líquidos de subsídios a produtos, utilizou-se a estrutura do total de impostos disponível por grupo de produtos nas TRU de 2017, e para a estimação do valor da produçáo, foi utilizada a estrutura do valor da produção total das TRU de 2017.

A estimação dos indicadores de consumo final, de formação bruta de capital (FBC) e de consumo intermediário foi realizada a partir do conceito de consumo aparente, que identifica a parcela da oferta total que foi efetivamente destinada para a demanda doméstica. Nesse sentido, a estimação desses agregados exclui o que foi destinado às exportaçôes do total da oferta. A agregação do indicador de consumo final é realizada por meio da agregação da estrutura de consumo final ${ }^{4}$ presente nas TRU de 2017. A FBC, por ser composta pela formaçáo bruta de capital fixo (FBCF) e pela variação de estoques, não é estimada agregadamente, uma vez que não há indicadores conjunturais que permitam analisar a evolução da variação de estoques. Por essa razão, a FBC é estimada de maneira semelhante à estimação do consumo final, a partir da estrutura desse agregado conforme a TRU de 2017.

A partir da estimativa do consumo final e da FBC, agregam-se as informaçóes de acordo com a estrutura da demanda final (consumo final + FBC + variação de estoques), com exclusão da variação de estoques, ${ }^{5}$ adotando-se a hipótese de que a agregação do consumo final com a FBC evolui de forma semelhante à demanda final. A partir da estimativa da série da demanda final, a série da variação de estoques é obtida como resíduo. Por fim, a estimação do consumo

1. Pesquisa Industrial Mensal de Produção Física (PIM-PF), Pesquisa Mensal do Comércio (PMC), Pesquisa Mensal de Serviços (PMS), Levantamento Sistemático da Produção Agrícola (LSPA), entre outras.

2. Dados do Departamento de Informática do Sistema Único de Saúde (DataSUS), de produção de petróleo e gás da Agência Nacional do Petróleo, Gás Natural e Biocombustíveis (ANP), de consumo de energia elétrica da Empresa de Pesquisa Energética (EPE), entre outras.

3. Para junho, como diversas informações ainda não estavam disponíveis no momento da confecção deste artigo, foram utilizadas projeções elaboradas pela autora com base nas sondagens da Fundação Getulio Vargas (FGV) e dados da Associação Brasileira do Papelão Ondulado (ABPO), da Associação Nacional dos Fabricantes de Veículos Automotores (ANFAVEA) e da Associação Brasileira de Captadores de Recursos (ABCR).

4. Composta por consumo das famílias, consumo das Instituições Sem Fim Lucrativo ao Serviço das Famílias (ISFLSF) e consumo do governo. 5. De 1998 a 2017 esse agregado representou 0,7\% do produto interno bruto (PIB), em módulo. 
intermediário também é obtida como resíduo, uma vez que a demanda final foi estimada e a demanda total também a partir da identidade que mostra que a oferta a preços do consumidor é igual à demanda total. A diferença entre a série de demanda total e demanda final, portanto, resulta na série de consumo intermediário. 